\title{
E-Marketplace Acceptance of MSMEs in Bali Based on Performance Expectancy and Task Technology Fit
}

\author{
Nyoman Sri Subawa \\ Faculty of Economic and Business, \\ Universitas Pendidikan Nasional \\ Jl. Bedugul No. 39 \\ Sidakarya, Denpasar, Indonesia \\ shribawa@undiknas.ac.id
}

\author{
Caren Angellina Mimaki \\ Faculty of Economic and Business, \\ Universitas Pendidikan Nasional \\ Jl. Bedugul No. 39 \\ Sidakarya, Denpasar, Indonesia
}

\begin{abstract}
Micro, Small, and Medium Enterprises (MSMEs) plays an important role in a country's economic growth especially in those developing countries. Nonetheless for this industry to continue grow and sustain, entrepreneurs need to be actively involved in emarketplace as many consumers now prefer to do online purchases or transactions since it is convenient. Thus, this paper aimed to study the e-marketplace acceptance in terms of performance expectancy and task technology fit by the entrepreneurs in selected provinces of Bali. The questionnaire of this study was distributed among 100 entrepreneurs from Gianyar, Denpasar and Badung. Data from the questionnaire were analyzed using and IBM SPSS software and SmartPLS software. Analysis of the results showed that performance expectancy had positive influence towards the entrepreneurs' intention in adopting e-marketplace with $\mathrm{p}=0.010$ and t-statistic $=2.617$. However, there was no significant impact of task technology fit towards acceptance of e-marketplace by the entrepreneurs with $\mathrm{p}=0.234$ and t-statistic $=1.197$.
\end{abstract}

\section{CCS CONCEPTS}

-Information systems $\sim$ Enterprise applications $\sim$ Information systems $\sim$ E-commerce infrastructure

\section{KEYWORDS}

e-marketplace, performance expectancy, task technology fit, MSMEs

\section{ACM Reference format:}

Nyoman Sri Subawa, Caren Angellina Mimaki. 2019. E-Marketplace Acceptance of MSMEs in Bali Based on Performance Expectancy and Task Technology Fit. In Proceedings of 2019 International Conference on EBusiness, Information Management and Computer Science (EBIMCS2019). December, 2019, Kuala Lumpur, Malaysia. ACM, New York, NY, USA. 4 pages. https://doi.org/10.1145/3377817.3377838.

\footnotetext{
*Article Title Footnote needs to be captured as Title Note

${ }^{\dagger}$ Author Footnote to be captured as Author Note

Permission to make digital or hard copies of part or all of this work for personal or classroom use is granted without fee provided that copies are not made or distributed for profit or commercial advantage and that copies bear this notice and the full citation on the first page. Copyrights for third-party components of this work must be honored. For all other uses, contact the owner/author(s). EBIMCS2019, December, 2019, Kuala Lumpur, Malaysia (C) 2019 Copyright held by the owner/author(s). 978-1-4503-6649-6/19/12..\$15.00 https://doi.org/10.1145/3377817.3377838
}

\section{INTRODUCTION}

Being one of the most populated countries in Southeast Asia, Indonesia' trading and industrial sector encompasses of Micro, Small, and Medium Enterprises (MSMEs). The definition and concept of MSMEs varies in each country. In Indonesia, MSMEs are categorized in two perspectives. First, based on assets which is regulated in Law No. 20 of 2008 which stated that "small businesses are productive economic activities of its own, which is done by the individual or business entity that is not a subsidiary or not the branch company owned, controlled, or be a part either directly or indirectly, of a medium or large businesses that meet the criteria for small businesses." Second, based on number of workers which is regulated in Badan Pusat Statistika 2015.

According to Ahmad and Siraj [1], Small and Medium Enterprises (SME) have proven to be contributing to the economic development of any country especially towards its Gross Domestic Product (GDP). SMEs play five major roles in improving a country's economic growth. First, SMEs have a position as a major player in economic activities in various sectors. Second is the role of SMEs in providing employment so that the unemployment rate decreases. Third, SMEs play a role in developing local economic activities and in community empowerment. The fourth role is that SMEs are the creators of new markets and sources of innovation. Last but not least, SMEs contribute high to GDP and maintain a balance of payments through export activities. Given these crucial role in a country, MSMEs need to be continuously developed so that it can bloom into a large business, thence compete globally. Harvie [2] has agreed that in order for MSMEs to grow, it require knowledge and skills acquisition, technology upgrading, improved product quality and competitiveness, innovation, and entrepreneurial activity. One of the methods to achieve this is to make use of the advanced information technology and penetrate the e-commerce marketplace, considering the increasing number of online consumers.

Several studies have been carried out on the adoption of emarketplace by MSMEs worldwide. Nurunnisha and Dalimunthe [3] studied on the factors influencing technology acceptance of ecommerce in Bandung by applying Technology Acceptance Model (TAM). Their findings revealed that from the percentage of influence toward behavioural intention, perceived usefulness has higher total effect value $(56.0 \%)$ compared to perceived ease of use. Based on the Technological, Organizational and Environmental(TOE) framework, the survey conducted by Rahayu 
and Day [4] on 292 SMEs, is was shown that perceived benefits, technology readiness, owners' innovativeness, owners' information technology (IT) ability and owners' IT experience are the determinant factors that influence Indonesian SMEs in their adopting e-commerce. Similar results were also obtained by Thabit et al.[5] in their study done within SMEs in Iraq. As for West Java, Indonesia, Maryeni et al. [6] reported that based on technology, organization, environment framework (TOE), the acceptance of ecommerce is strongly influenced by complexity, IT planning, users IT skill, and management support. A comprehensive review done by Hayati and Andrawina [7], concluded that there are four external dimensions and five internal dimensions affecting e-commerce adoption. The external dimensions are institutional environment, economic environment, socio-cultural environment, and technology environment. Meanwhile, the internal dimensions consist of managerial demography, company's size, company's capabilities, corporate strategy, and company's knowledge management.

Despite these researches conducted, there were scarcely study done on the adoption of e-marketplace of the MSMEs in the province of Bali focusing on performance expectancy and task technology fit. Hence, this paper is to scrutinize how these two factors impact the behavioral intention of adopting e-marketplace among the entrepreneurs in three selected regencies of Bali. The two hypotheses proposed in this study were as listed below:

H1: Performance expectancy has a positive relationship towards behavior intention to utilize e-marketplace.

$\mathrm{H} 2$ : Task technology fit has a positive relationship towards behavior intention in employing e-marketplace.

\section{METHODOLOGY}

\subsection{Research Location}

This study was carried out in the three main regencies of Bali namely Badung, Denpasar, and Gianyar. The reason for selecting these three locations is due to the economic level of growth and the number of MSMEs in those areas.

\subsection{Research Population and Sample}

The population of this study covered the MSMEs in nine regencies of Bali which are Badung, Bangli, Buleleng, Gianyar, Jembrana, Karangasem, Klungkung, Tabanan, and Denpasar. Nonetheless, since the research is conducted only in three out of the nine regencies, the samples of this study are those MSMEs entrepreneurs who use e- marketplaces in the aforementioned three regencies (Badung, Denpasar, and Gianyar).

The sampling technique applied in this study is cluster sampling. Calculations using the cluster sampling technique are determined from the total population in each district divided by the total population in the three regencies, then multiplied by the minimum number of samples in Partial Least Square Structural Equation Model (PLS-SEM). For a large population of study using PLS approach, it was recommended by Ghozali [8] that the sample size should at least be between 30 and 100 . Hence, this study used a sample of 100 respondents. Based on this equation model, the number of samples for each of the regencies were approximately 44.4 45, 31.3 31 and 24.2 24 for Denpasar, Badung and Gianyar respectively. The MSMEs selected as the sample of this study need to meet the criteria which are the MSMEs must be internet users, have an account in one e-marketplace, and have transacted online.

\subsection{Data Collection}

Questionnaire was the research instrument used for this study. in the prepared questionnaire, a 5-point Likert scale was used to measure the responses to the questions where each question is divided into 5 measuring scales namely strongly agree (score 5), agree (score 4), neutral (score 3), disagree (score 2), and strongly disagree (score 1). The questionnaire was designed in English, but also translated into Bahasa for the convenience of the participants.

The questionnaires were distributed to 45 respondents in Denpasar, 31 respondents in Badung and 24 respondents in Gianyar in MSMEs. Questionnaires that have been filled out and returned by respondents were selected in advance so that questionnaires that are incomplete in filling are not included in the data analysis.

\subsection{Data Analysis}

Once all the questionnaires have been returned, the data were analyzed using SmartPLS software. These data were analyzed using descriptive statistical analysis that displayed research data in the form of mean scores in IBM SPSS Statistic software version 25, and inferential analysis using PLS-SEM (Partial Least SquaresStructural Equation Model) analysis techniques. The hypotheses were tested using PLS- SEM analysis techniques, because this research was conducted using a model of causality or influence relations

\subsection{Operational Variable Definitions}

The definition for each of the variables used in this study is explained as in Table 1.

Table 1. Operational variable definitions [9-12]

\begin{tabular}{|l|c|}
\hline \multicolumn{1}{|c|}{$\begin{array}{c}\text { Variable and } \\
\text { Definition }\end{array}$} & Indicators \\
\hline $\begin{array}{l}\text { Performance } \\
\text { Expectancy (PE) : } \\
\text { The degree to which } \\
\text { and individual believes } \\
\text { that using the system } \\
\text { will help him or her to } \\
\text { attain gains in job } \\
\text { performance }\end{array}$ & $\begin{array}{l}\text { Using e-marketplace in my } \\
\text { job would enable me to } \\
\text { accomplish tasks more } \\
\text { quickly }\end{array}$ \\
$\begin{array}{l}\text { Using e-marketplace would } \\
\text { improve my job } \\
\text { performance and efficiency }\end{array}$ \\
$\begin{array}{l}\text { Using e-marketplace in my } \\
\text { job would increase my } \\
\text { productivity }\end{array}$ \\
\hline $\begin{array}{l}\text { Task Technology Fit } \\
\text { (TTF): Features of a } \\
\text { technology match the } \\
\text { requirements of the }\end{array}$ & $\begin{array}{l}\text { Task Technology Fit } \\
\text { E-marketplace are well suited for } \\
\text { our business daily routine tasks }\end{array}$ \\
\hline
\end{tabular}




\begin{tabular}{|l|ll|}
\hline $\begin{array}{l}\text { task and the abilities of } \\
\text { the individuals } \\
\text { performing the task. }\end{array}$ & $\bullet \begin{array}{l}\text { Function of E-marketplace is } \\
\text { very adequate for our MSME } \\
\text { Business } \\
\text { In my opinions, E-marketplace's } \\
\text { functions are enough to help me } \\
\text { complete my work or } \\
\text { coursework }\end{array}$ \\
\hline
\end{tabular}

\section{RESULTS AND DISCUSSION}

\subsection{Descriptive Statistics}

The descriptive statistics of the respondents' background are tabulated in Table 2. Based on Table 2, out of 100 respondents, 55 are males while the remaining 45 are females. Majority (58.0\%) of these MSMEs are also run by those between the age group of 2130 years old. Those MSMEs that were operated by entrepreneurs below 20 years old are only 24 . The levels of experience of the respondents are split into five categories. Among these five categories, 48 respondents have experience within 2-3 years dealing with e-marketplace. Meanwhile, those with less than a year experience, 4-6 years of experience, and 7-9 years of experience are 17 respondents, 34 respondents and 1 respondent respectively.

Table 2. Descriptive statistics of respondents

\begin{tabular}{|l|c|c|}
\hline & Number of Respondents & Percentage \\
\hline Gender & & \\
\hline Male & 55 & $55.0 \%$ \\
\hline Female & 45 & $45.0 \%$ \\
\hline Age & & \\
\hline$\leq 20$ & 24 & $24.0 \%$ \\
\hline $21-30$ & 58 & $58.0 \%$ \\
\hline $31-40$ & 18 & $18.0 \%$ \\
\hline$\geq 41$ & 0 & $0 \%$ \\
\hline Experience & & \\
\hline Less than 1 year & 17 & $17.0 \%$ \\
\hline 2-3 years & 48 & $48.0 \%$ \\
\hline 4-6 years & 34 & $34.0 \%$ \\
\hline 7-9 years & 1 & $1.0 \%$ \\
\hline Total & 100 & $100 \%$ \\
\hline
\end{tabular}

Table 3 presented the descriptive statistical test conducted on the variables of this study.

PE construct data was obtained from distributing questionnaires online with the number of questions as many as 3 items by using a 5-point Likert Scale, having a theoretical score between the lowest score of 3 to the highest score of 15 . The empirical score on the emarketplace adoption model spreads from the lowest score of 9 to the highest score of 15, with a total score of 1313, mean 13.13 and standard deviation of 1.606 .

The TTF construct data was obtained from distributing questionnaires online with the number of questions as many as 3 items with the use of a 5-point Likert Scale, having a theoretical score between the lowest score of 3 to the highest score of 15 . The empirical score on the e- marketplace adoption model spreads from the lowest score of 9 to the highest score of 15 , with a total score of 1301, mean 13.01 and standard deviation of 1.636 .

The BI construct data was obtained from distributing questionnaires online with the number of questions of 3 items with the use of a 5-point Likert Scale, having a theoretical score between the lowest score of 3 to the highest score of 15 . The empirical score on the e-marketplace adoption model spreads from the lowest score of 9 to the highest score of 15 , with a total score of 1363 , mean 13.63 and standard deviation 1.461 .

Table 3. Descriptive statistical test of the variables

\begin{tabular}{|l|c|c|c|c|c|c|}
\hline \multicolumn{2}{|c|}{ N } & Minimum & Maximum & Sum & Mean & $\begin{array}{c}\text { Std. } \\
\text { Deviation }\end{array}$ \\
\hline $\begin{array}{l}\text { Performance } \\
\text { Expectancy } \\
\text { (PE) }\end{array}$ & 100 & 9 & 15 & 1313 & 13.13 & 1.606 \\
\hline $\begin{array}{l}\text { Task } \\
\text { Technology } \\
\text { Fit (TTF) }\end{array}$ & 100 & 9 & 15 & 1301 & 13.01 & 1.636 \\
\hline $\begin{array}{l}\text { Behavioral } \\
\text { Intention (BI) }\end{array}$ & 100 & 9 & 15 & 1363 & 13.63 & 1.461 \\
\hline $\begin{array}{l}\text { Valid N } \\
\text { (listwise) }\end{array}$ & 100 & & & & & \\
\hline
\end{tabular}

\subsection{Model Evaluation}

\subsubsection{Convergent Validity}

The validity test of the reflective convergent indicator by using the SmartPLS 3.0 program can be seen from the loading factor value and the average variance extracted (AVE) value. The rule of thumb used in testing convergent validity with the loading factor value must be more than 0.7 for confirmatory research and a value between 0.6-0.7 is acceptable for explanatory research. SmartPLS output for loading factors that produce the appropriate results can be seen in the Table 4.

Based on the output loading it can be seen that the results of the loading factor of all the indicators of each construct have fulfilled the convergent validity, because the loading factor value of each indicator has shown a value greater than the recommended which is 0.6. Therefore, it can be said that the indicators used in this study are valid or have fulfilled the convergence validity.

Table 4. Output for loading factors

\begin{tabular}{|c|c|c|c|}
\hline & PE & TTF & BI \\
\hline PE1 & 0.792 & & \\
\hline PE2 & 0.856 & & \\
\hline PE3 & 0.835 & & \\
\hline TTF1 & & 0.794 & \\
\hline TTF2 & & 0.844 & \\
\hline TTF3 & & 0.853 & \\
\hline BI1 & & & 0.838 \\
\hline
\end{tabular}


E-Marketplace Acceptance of MSMEs in Bali Based on Performance Expectancy and Task Technology Fit

\begin{tabular}{|c|l|l|l|}
\hline $\mathrm{BI} 2$ & & & 0.698 \\
\hline $\mathrm{BI} 3$ & & & 0.891 \\
\hline
\end{tabular}

Note: PE - Performance expectancy, TTF - Task technology fit, BI- Behavioral Intention

\subsubsection{Average Variance Extracted (AVE)}

Validity testing can also be done by looking at the value of Average Variance Extracted (AVE). The recommended AVE value must be greater than 0.5. The outputs of AVE on the adoption model of emarketplace are tabulated in Table 5. Performance expectancy, task technology fit, and behavioral intention have AVE values greater than 0.5 which means that the indicator used in this study are valid or have fulfilled the convergence validity.

Table 5. E-marketplace adoption model AVE results

\begin{tabular}{|l|c|}
\hline \multicolumn{1}{|c|}{ Construct } & $\begin{array}{c}\text { Average Variance } \\
\text { Extracted (AVE) }\end{array}$ \\
\hline Performance Expectancy (PE) & 0.686 \\
\hline Task Technology Fit (TTF) & 0.690 \\
\hline Behavior Intention (BI) & 0.661 \\
\hline
\end{tabular}

\subsection{Hypothesis Testing}

The bootstrapping results of the two variables towards behavioral intention (BI) are shown in Table 6.

This research model validates relationship between performance expectancy (PE) and Behavioral Intention (BI). The findings of this study shows that $\mathrm{PE}$ has a direct positive effect on the behavioral intention the adoption of e-marketplace among MSMEs, $\mathrm{p}<0.05$ and $\mathrm{t}$-statistic $=2.617>1.960$. The significant effect was in accordance with the results found by Venkatesh et al. [9], Mursalin and Al [13] and Humaid and Ibrahim [14] which indicates that there is a strong influence between PE on BI in using a system. Thus, the hypothesis is accepted. The more perceived benefits and usefulness of e-marketplace in assessing business tasks of MSMEs, it will exert a positive impact on the intention to adopt the system.

The association between TTF and BI were insignificant and shows negative sign in the e-marketplace adoption $(\mathrm{p}>0.05, \mathrm{t}-$ statistic $=1.197<1.960)$. Thus, it did not support the hypothesis. This finding is in accordance with Oliveira et al.[15] (Oliveira et al., 2014 where TTF could not explain the effect towards behavior intention in adopting m-banking. The reason that can underlie the existence of insignificance is that there are still many MSMEs which do not understand how to operate e-marketplaces in business rather than just installing products. Perhaps many MSMEs do not yet understand the techniques of selling products in a good emarketplace to make a profit. In addition, there maybe some MSMEs which prefer to focus on selling on other online platforms, such as s-commerce so that the results obtained are not significant.

Table 6. E-marketplace model adoption bootstrapping results
EBIMCS 2019, December, 2019, Kuala Lumpur, Malaysia

\begin{tabular}{|l|c|c|c|}
\hline & $\begin{array}{c}\text { Original Sample } \\
(\mathbf{O})\end{array}$ & $\begin{array}{c}\text { T Statistics } \\
(\mid \mathbf{O} / \text { STDEV } \mid)\end{array}$ & $\begin{array}{c}\mathbf{P} \\
\text { Values }\end{array}$ \\
\hline PE -> BI & 0.313 & 2.617 & 0.010 \\
\hline TTF -> BI & -0.118 & 1.197 & 0.234 \\
\hline
\end{tabular}

Note: PE - Performance expectancy, TTF - Task technology fit, BI- Behavioral Intention

\section{CONCLUSION}

Based on the findings of this study, it is proven that performance expectancy has positive significant influence towards behavioral intention of MSMEs in adopting e-marketplace. Nonetheless, the factor 'task technology fit' has insignificant impact of behavioral intention in adopting e-marketplace which is implied by the negative value of the path coefficient, -0.118 .

\section{REFERENCES}

[1] Ahmad, M., \& Siraj, S. (2018). A systematic review and analysis of determinants impacting adoption and assimilation of e-commerce in small and medium enterprises. International Journal of Electronic Business, 14(4), 326351.

[2] Harvie, C. (2019). Micro-, Small-and Medium-Sized Enterprises (MSMEs): Challenges, Opportunities and Sustainability in East Asia. In Trade Logistics in Landlocked and Resource Cursed Asian Countries (pp. 155-174). Palgrave Macmillan, Singapore.

[3] Nurunnisha, G. A., \& Dalimunthe, G. P. (2018). The Effect of E-Commerce Awareness in E-Commerce Technology Acceptance on MSME in Bandung. DeReMa (Development Research of Management): Jurnal Manajemen, 13(2), 198-217.

[4] Rahayu, R., \& Day, J. (2015). Determinant factors of e-commerce adoption by SMEs in developing country: evidence from Indonesia. Procedia-Social and Behavioral Sciences, 195, 142-150.

[5] Thabit, T. H., Raewf, M. B., Abdulrahman, O. T., \& Younis, S. K. (2016). The Adoption of E-commerce in SMEs A case study on a sample of Iraqi enterprises. International Journal of Latest Research in Engineering and Technology, 2(06), $38-46$.

[6] Maryeni, Y. Y., Govindaraju, R., Prihartono, B., \& Sudirman, I. (2014). Ecommerce adoption by Indonesian SMEs. Australian Journal of Basic and Applied Sciences, 8(14), 45-49.

[7] Hayati, I., \& Andrawina, L. (2019, August). Comprehensive Framework of Ecommerce Adoption in Indonesian SMEs. In IOP Conference Series: Materials Science and Engineering (Vol. 598, No. 1, p. 012065). IOP Publishing.

[8] Ghozali, I. (2008). Structural equation modeling: Metode alternatif dengan partial least square ( $p l s)$. Badan Penerbit Universitas Diponegoro.

[9] Venkatesh, V., Morris, M. G., Davis, G. B., \& Davis, F. D. (2003). User acceptance of information technology: Toward a unified view. MIS quarterly, 425-478.

[10] Venkatesh, V., Thong, J. Y., \& Xu, X. (2012). Consumer acceptance and use of information technology: extending the unified theory of acceptance and use of technology. MIS quarterly, 36(1), 157-178.

[11] Wamuyu, P. K. (2017). Use of cloud computing services in micro and small enterprises: a fit perspective.

[12] Lu, H. P., \& Yang, Y. W. (2014). Toward an understanding of the behavioral intention to use a social networking site: An extension of task-technology fit to social-technology fit. Computers in Human Behavior, 34, 323-332.

[13] Mursalin, M., \& Al, J. (2012). Information system adoption and usage: Validating UTAUT model for Bangladeshi SMEs.

[14] Humaid, A. B., \& Ibrahim, Y. M. (2019). The Examination of Factors Influencing Saudi Small Businesses ${ }^{-}$Social Media Adoption, by Using UTAUT Model International Journal of Business Administration, 10(2), 96-114.

[15] Oliveira, T., Faria, M., Thomas, M. A., \& Popovič, A. (2014). Extending the understanding of mobile banking adoption: When UTAUT meets TTF and ITM International Journal of Information Management, 34(5), 689-703. 